\title{
Dynamic Expression of Lgr5, a Wnt Target Gene, in the Developing and Mature Mouse Cochlea
}

\author{
Renjie Chai ${ }^{1}$, Anping Xia ${ }^{1}$, Tian Wang $^{1}$, Taha Adnan Jan ${ }^{1}$, Toshinori Hayashi ${ }^{2,3}$, \\ Olivia Bermingham-McDonogh ${ }^{2}$, and Alan Gi-Lun Cheng ${ }^{1}$ \\ ${ }^{1}$ Department of Otolaryngology-Head and Neck Surgery, Stanford University, 801 Welch Road, Stanford, CA 94305, USA \\ ${ }^{2}$ Department of Biological Structure, University of Washington, 815 Mercer Street Box 358056, Seattle, WA 98109, USA \\ ${ }^{3}$ Division of Bio-signaling, School of Life Science, Faculty of Medicine, Tottori University, 86 Nishi-Machi, Yonage City, Tottori \\ Prefecture 683-8503, Japan
}

Received: 6 January 2011; Accepted: 17 March 2011; Online publication: 7 April 2011

\begin{abstract}
The Wnt signaling pathway is a recurring theme in tissue development and homeostasis. Its specific roles during inner ear development are just emerging, but few studies have characterized Wnt target genes. Lgr5, a member of the $\mathrm{G}$ protein-coupled receptor family, is a Wnt target in the gastrointestinal and integumentary systems. Although its function is unknown, its deficiency leads to perinatal lethality due to gastrointestinal distension. In this study, we used a knock-in reporter mouse to examine the spatiotemporal expression of $\operatorname{Lgr} 5$ in the cochlear duct during embryonic and postnatal periods. In the embryonic day 15.5 (E15.5) cochlear duct, Lgr5-EGFP is expressed in the floor epithelium and overlapped with the prosensory markers Sox2, Jagged1, and p27 (Kip1). Nascent hair cells and supporting cells in the apical turn of the E18.5 cochlear duct express Lgr5EGFP, which becomes downregulated in hair cells and subsets of supporting cells in more mature stages. In situ hybridization experiments validated the reporter expression, which gradually decreases until the second postnatal week. Only the third row of Deiters' cells expresses Lgr5-EGFP in the mature organ of Corti. Normal cochlear development was observed in $\operatorname{Lgr} 5^{\mathrm{EGFP} / \mathrm{EGFP}}$ and $\operatorname{Lgr} 5^{\mathrm{EGFP} /+}$ mice, which exhibited
\end{abstract}

Present address: Toshinori Hayashi, Division of Bio-signaling, School of Life Science, Faculty of Medicine, Tottori University, 86 NishiMachi, Yonage City, Tottori Prefecture 683-8503, Japan.

Correspondence to: Alan Gi-Lun Cheng · Department of OtolaryngologyHead and Neck Surgery - Stanford University - 801 Welch Road, Stanford, CA 94305, USA. Telephone: +1-650-7216962; fax: +1-6507212163; email: aglcheng@stanford.edu normal auditory thresholds. The expression pattern of $\operatorname{Lgr} 5$ contrasts with another Wnt target gene, Axin2, a feedback inhibitor of the Wnt pathway. Robust Axin 2 expression was found in cells surrounding the embryonic cochlear duct and becomes restricted to tympanic border cells below the basilar membrane in the postnatal cochlea. Both Lgr5 and Axin2 act as Wnt targets in the cochlea because purified Wnt3a promoted and Wnt antagonist suppressed their expression. Their differential expression among cell populations highlights the dynamic but complex distribution of Wnt-activated cells in and around the embryonic and postnatal cochlea.

Keywords: hair cells, supporting cells, Axin2, B-catenin, prosensory, Deiters' cells

\section{INTRODUCTION}

The canonical Wnt pathway is highly conserved and mediates organogenesis in multiple systems throughout development and into adulthood (Logan and Nusse 2004). Wnts comprise a family of 19 secreted proteins that regulate various developmental events including cell proliferation, cell fate specification, and differentiation in a highly context-dependent manner. In the absence of Wnt ligands, $B$-catenin is degraded and maintained at a low cytoplasmic level (Fig. 1). When Wnt proteins bind to one of the 12 Frizzled receptors as well as the low density lipoprotein-related protein co-receptors (LRP5/6), the destruction com- 


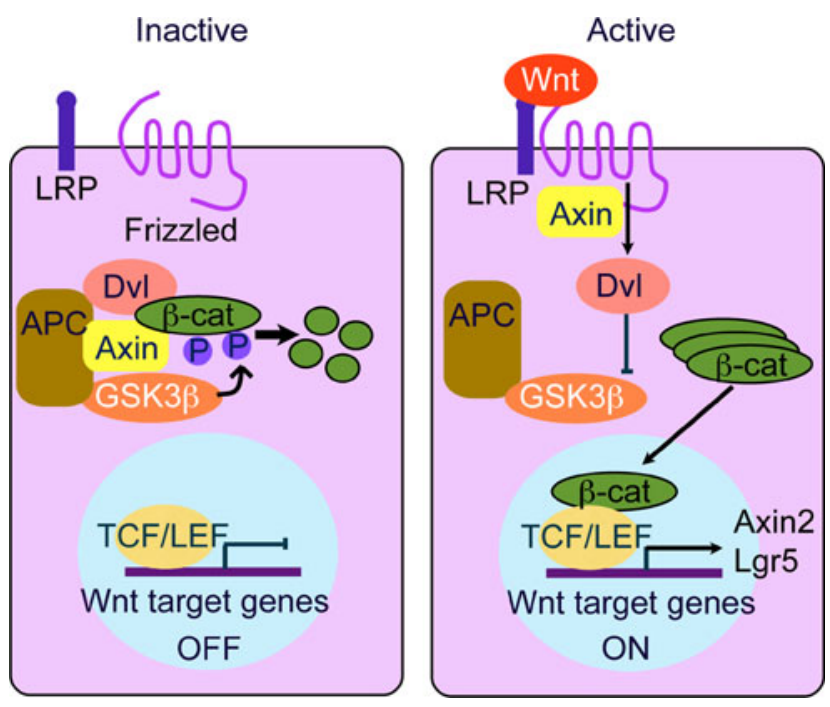

FIG. 1. Schematic for canonical Wnt signaling (modified from Reya and Clevers 2005). Wnt proteins are ligands for Frizzled receptors and low-density lipoprotein receptor-like proteins ( $L R P)$ co-receptors. In the absence of Wnt proteins, the destruction complex, which consists of Axin, adenomatous polyposis coli (APC) tumor suppressor protein, and glycogen synthase kinase $3 \beta(G S K 3 \beta)$, phosphorylates and degrades $\beta$-catenin, which is kept at a low cytoplasmic level. Upon activation by Wnt proteins, disheveled $(D v l)$ is recruited to the receptor complex and Axin is sequestered. Consequently, ß-catenin accumulates and migrates into the nucleus to bind T cell factor/ lymphoid enhancer factor (TCF/LEF), which in turn activates Wnt target genes.

plex for ß-catenin becomes inactivated and allows it to accumulate and, ultimately, to migrate into the nucleus. The binding of $\beta$-catenin to $\mathrm{T}$ cell factor (TCF/LEF)/lymphoid enchancer factor activates Wnt target genes. Knockout models of Wnt family members demonstrate defects in the neural tube (Ikeya et al. 1997), lungs (Li et al. 2002), limbs (Yamaguchi et al. 1999), and kidneys (Majumdar et al. 2003).

In the developing inner ear, strict control of cell proliferation and differentiation is essential. The cochlear duct develops as a ventral outpouching of the otocyst around embryonic day 11 (E11). Starting at E13, cells in a specific region in the floor of the cochlear duct exit the cell cycle and subsequently differentiate into cells comprising the organ of Corti (Ruben 1967). Chen and Segil (1999) described this area as the zone of nonproliferating (ZNP) cells, which begin to express the cyclin-dependent kinase inhibitor p27(Kip1). While cell lineage analyses have not been conducted, most cells in the postnatal organ of Corti are presumed to derive from these ZNP cells, which include the cochlear prosensory domains (Chen et al. 2002; Chen and Segil 1999). As the wave of terminal mitoses progresses from the apex toward the basal turn of the cochlea between E12.5 and E16 (Lee et al. 2006; Ruben 1967), cellular differentiation within the prosensory domain expands from the mid-basal region toward the apical and basal poles (Rubel 1978). Multiple genes are expressed within the cochlear prosensory domain, including Jagged1, Islet1, Lunatic fringe, Prox1, Sox2, and Fgf20 (Bermingham-McDonogh et al. 2006; Dabdoub et al. 2008; Hayashi et al. 2008; Kiernan et al. 2005; Morrison et al. 1999; Morsli et al. 1998; Radde-Gallwitz et al. 2004). Wnt/ß-catenin signaling is involved in the specification of otic cell identity, dorsal patterning of the otocyst, as well as eventual formation of the vestibular organs (Hollyday et al. 1995; Jasoni et al. 1999; Lillevali et al. 2006; Ohyama et al. 2006; Riccomagno et al. 2005). However, few studies have examined the role of this signaling pathway in the developing cochlea in the late embryonic age. Several Wnt proteins and Frizzled receptors are expressed in the developing cochlear duct and postnatal organ of Corti (Dabdoub and Kelley 2005; Daudet et al. 2002; Sienknecht and Fekete 2008, 2009). Because the large number of possible ligand-receptor combinations and redundancies makes deciphering the exact individual functions of Wnt proteins and Frizzled receptors difficult, many investigators have taken advantage of Wnt target genes to identify cells with active Wnt signaling (Barolo 2006; Logan and Nusse 2004). Our study utilizes transgenic reporters to investigate the spatiotemporal expression of Wnt target genes in the mammalian cochlear duct to identify regions and cell types that display active Wnt/ß-catenin signaling. Here, we report the differential expression patterns of two Wnt target genes, Lgr5 and Axin2, within the embryonic and postnatal cochlea.

\section{METHODS}

\section{Animals}

$\operatorname{Lgr} 5^{\text {EGFP-Ires-CreERT2/+ }}\left(\operatorname{Lgr} 5^{\text {EGFP/+}}\right)$ mice (Barker et al. 2007) in a C57BL/6J background were purchased from the Jackson Laboratory (stock no. 008875; Bar Harbor, ME). Homozygous Lgr5-deficient mice die perinatally (Morita et al. 2004). Knock-in of the gene encoding enhanced green fluorescent protein (EGFP) into the first exon of Lgr5 results in the expression of EGFP that faithfully represents $\operatorname{Lgr} 5$ expression in the heterozygotes with no reported phenotypes (Barker et al. 2007). Axin $2^{\mathrm{LacZ} /+}$ mice in a CD1 background (Jho et al. 2002; Lustig et al. 2002) were a generous gift from R. Nusse (Stanford, CA). Axin $2^{\mathrm{LacZ} /+}$ heterozygous animals display no gross cochlear malformation and no auditory brainstem response $(\mathrm{ABR})$ threshold shifts in comparison to wild-type littermates at postnatal day 30 (P30, unpublished data). Axin $2^{\mathrm{LacZ} /+}$ mice also utilize a faithful knock-in reporter, the LacZ gene encoding the bacterial ß-galactosidase gene. Besides normal cochlear morphology and ABR thresholds, no phenotype has been reported in heterozygous Axin $2^{\mathrm{LacZ} /+}$ mice 
(Soshnikova et al. 2003). At least three animals were examined at each developmental time point. The Stanford University Institutional Animal Care and Use Committee approved all experimental procedures.

\section{Genotyping and RT-PCR and qPCR}

Transgenic mice were genotyped using genomic DNA which was isolated by adding $200 \mu \mathrm{l} 50 \mathrm{mM} \mathrm{NaOH}$ to cut tail tips, incubated at $98^{\circ} \mathrm{C}$ for $1 \mathrm{~h}$, followed by the addition of $20 \mu \mathrm{l}$ of $1 \mathrm{M} \mathrm{HCl}$. We used the following genotyping primers: $\operatorname{Lgr} 5$ : wild-type forward, $5^{\prime}$ CTGCTCTCTGCTCCCAGTCT-3'; reverse, 5'-ATACCC CATCCCTTTTGAGC-3'; mutant reverse, 5'-GAACTT CAGGGTCAGCTTGC-3'. Axin2: wild-type forward, 5'AAGCTGCGTCGGATACTTGAGA-3'; reverse, 5' AGTCCATCTTCATTCCGCCTAGC-3'; mutant reverse, 5'-TGGTAATGCTGCAGTGGCTTG-3' .

For reverse transcriptase polymerase chain reaction (RT-PCR) and quantitative polymerase chain reaction (qPCR), total RNA isolation (from P3 and P15 wild-type cochleae with the stria vascularis and modiolus microdissected away, or Lgr5-EGFP-positive and -negative cells isolated from P3 $\mathrm{Lgr}^{\mathrm{EGFP} /+}$ cochleae via flow cytometry) was carried out using Qiagen RNeasy mini extraction kits (Qiagen, Valencia, CA), followed by cDNA synthesis using SuperScript III First-Strand Synthesis System kits (Invitrogen, Carlsbad, CA). qPCR reactions were performed with SYBR Green PCR Master Mix (Applied Biosystems, Carlsbad, CA) on a 7900HT Fast Real-Time PCR System (Applied Biosystems). Each PCR reaction was carried out in triplicate and the relative quantification of gene expression analyzed using the $\Delta \Delta C_{\mathrm{T}}$ method with $\beta$-actin as the endogenous reference (Livak and Schmittgen 2001).

Primer pairs were designed using the online Primer3 software available at http://frodo.wi.mit.edu/primer3/. Lgr5: forward, 5'-TCTTCACCTCCTACCTGGACCT-3'; reverse, 5'-GGCGTAGTCTGCTATGTGGTGT-3'; Sox2: forward, 5' ${ }^{\prime}$-ATGAACGGCTGGAGCAACGGCA-3' reverse, 5'-TCACATGTGCGACAGGGGCAGT-3'; Axin 2:

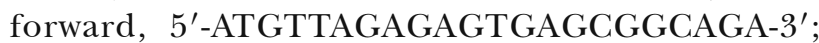
reverse, 5'-CTTCAGCATCGTCCTGTATGGA-3'; Brm3.1: forward, 5'-ACCCAAATTCTCCAGCCTACAC-3'; reverse, 5'-GGCGAGATGTGCTCAAGTAAGT-3'; $p 27$ (Kip1): forward, 5'-AAGCACTGCAGAGACATGGAAG-3'; reverse, 5'-GTAGAAGAATCGTCGGTTGCAG-3'; GAPDH: forward, 5'-AACGGGAAGCCC-ATCACCATCTT-3'; reverse, 5'-CAGCCTTGGCAGCACCAGTGG-3'; $\beta$-actin: forward, 5'-ACGGCCAGGTCATCACTATTG-3'; reverse, 5' AGGGGCCGGACTCATCGTA-3' .

\section{Cryosectioning}

Heads from E15.5-P3 and otic bullae from P6-30 mice were isolated and fixed with $4 \%$ paraformalde- hyde (Electron Microscopy Services, Hatfield, PA) in phosphate-buffered saline (PBS, $\mathrm{pH} 7.4$ ) at $4^{\circ} \mathrm{C}$ overnight. For P9 or older animals, decalcification was performed with $0.5 \mathrm{mM}$ EDTA in PBS for 1-3 days at $4^{\circ} \mathrm{C}$. Tissues were then cryoprotected by successively incubating them in $10 \%, 20 \%$, and $30 \%$ sucrose in PBS and then embedded in OCT compound (Sakura Finetek, Torrance, CA). Serial frozen sections of 10- to $12-\mu \mathrm{m}$ thickness were made with a Leica CM3050 cryostat (Leica, Bannockburn, IL).

\section{Tissue cultures}

Cochleae from $\operatorname{Lgr} 5^{\mathrm{EGFP} /+}$ mice were isolated under sterile conditions with the anlage of the stria vascularis, modiolus, and tectorial membrane removed with fine forceps. Whole-mount cochleae were then placed onto 10-mm coverslips (Fisher Scientific, Pittsburgh, PA) pre-coated with CellTaK (BD Biosciences, San Jose, CA). Whole organs were cultured in DMEM/F12 (Invitrogen) supplemented with N2 (Invitrogen), B27 (Invitrogen), epidermal growth factor $(20 \mathrm{ng} / \mathrm{ml})$, insulin-like growth factor $1(50 \mathrm{ng} / \mathrm{ml})$, basic fibroblast growth factor $(10 \mathrm{ng} / \mathrm{ml})$, heparan sulfate (50 $\mathrm{ng} / \mathrm{ml})$, and ampicillin $(50 \mu \mathrm{g} / \mathrm{ml}$; all from Sigma, St. Louis, MO) in four-well Petri dishes (Greiner Bio-one, Monroe, NC). Purified Wnt3a (200 $\mathrm{ng} / \mathrm{ml})$ and Fz8CRD $(25 \mu \mathrm{g} / \mathrm{ml}$, generously provided by R. Nusse) were synthesized and purified as previously described (DeAlmeida et al. 2007; Willert et al. 2003). Culture media were replenished every $1-2$ days.

\section{Flow cytometry}

Cochleae from P3 Lgr5 ${ }^{\mathrm{EGFP} /+}$ mice were dissected and incubated in $0.125 \%$ trypsin (Invitrogen) in PBS for $8 \mathrm{~min}$ at $37^{\circ} \mathrm{C}$. The reaction was terminated with the addition of soybean trypsin inhibitor $(6.7 \mathrm{mg} / \mathrm{ml}$; Worthington Biochem, Lakewood, NJ). Following trituration, cells were passed through a $40-\mu \mathrm{m}$ filter to achieve a single cell suspension. Propidium iodide $(1 \mu \mathrm{g} / \mathrm{ml}$, Sigma) was used to label nonviable cells. We routinely achieved 93-95\% cell viability. Cell sorting was performed on a BD Aria II FACS cytometer (BD Bioscience). Cochlear cells from wild-type mice were used as controls, and no GFP signals were detected.

Immunohistochemistry, image acquisition, and image analyses

Tissues were immersed in blocking solution consisting of $5 \%$ goat or donkey serum, $0.1 \%$ tritonX-100, $1 \%$ bovine serum albumin (BSA), and $0.02 \%$ sodium azide $\left(\mathrm{NaN}_{3}\right)$ in PBS at $\mathrm{pH} 7.4$ for $1 \mathrm{~h}$ at room 
temperature. Incubation with primary antibodies that were diluted in blocking solution was done overnight at $4^{\circ} \mathrm{C}$ in a humidified chamber. The following day, tissues were rinsed with PBS and then incubated with secondary antibodies diluted in $0.1 \%$ tritonX-100, $0.1 \% \mathrm{BSA}$, and $0.02 \% \mathrm{NaN}_{3}$ solution in PBS for $1 \mathrm{~h}$ at room temperature. After washing with PBS, tissues were mounted in antifade Fluorescence Mounting Medium (DAKO, Carpinteria, CA) and coverslipped. The following antibodies were used: anti-myosin7A (1:1,000, Proteus Bioscience, Ramona, CA; Oesterle et al. 2008); anti-p27(Kip1) (1:1,000, Fisher Scientific; Chen and Segil 1999); anti-Jagged1 (1:800, Santa Cruz Biotechnology, Santa Cruz, CA; Morrison et al. 1999); anti-Prox1 (1:1,000, Millipore; Bermingham-McDonogh et al. 2006); and antiSox2 (1:400 Santa Cruz Biotechnology; Hume et al. 2007). Monoclonal antibody against Lgr5 (1:1,000, clone FM4056) was generously provided by K. Masuda (Kyowa Hakko Kirin Company, Tokyo, Japan; Sasaki et al. 2010). The specificity of these antibodies has been confirmed in the referenced studies as well as by their respective suppliers. The secondary antibodies were conjugated with FITC, TRITC, or Cy5 (1:200, Jackson ImmunoResearch, West Grove, PA). Images were acquired using epifluorescence or confocal microscopy (Axioplan 2, Zeiss, Germany) and analyzed with Photoshop CS4 (Adobe Systems, San Jose, CA). Three-dimensional reconstruction of Z-stack images was performed using Volocity software (v5.3.0; Improvision, Waltham, MA).

\section{In situ hybridization}

In situ hybridization was performed as previously described (Hartman et al. 2009; Hayashi et al. 2007). Briefly, a digoxigenin-labeled probe was transcribed from a linearized Axin 2 clone (bp 1-2397, a generous gift of F. Costantini at Columbia University, NY) and a full-length $\operatorname{Lgr} 5$ clone (clone ID 100062127) obtained from Open Biosystems (Huntsville, AL). Heads of embryos were collected from timed pregnant wildtype Swiss Webster mice. For P0 or older mice, brains were removed from half-heads. These tissues were fixed overnight at $4^{\circ} \mathrm{C}$ in modified Carnoy's solution (60\% ethanol, $11.1 \%$ formaldehyde, $10 \%$ glacial acetic acid), dehydrated through an ethanol series, prepared for paraffin embedding $(2 \times 15$-min washes in xylene at RT and $3 \times 30 \mathrm{~min}$ in paraffin at $65^{\circ} \mathrm{C}$ ), and sectioned at $8 \mu \mathrm{m}$. Slides were incubated $2-4 \mathrm{~h}$ at $68^{\circ} \mathrm{C}$, deparaffinized in xylene $(2 \times 10 \mathrm{~min})$, rinsed in $100 \%$ ethanol, and air-dried at room temperature. Slides were then incubated in hybridization buffer for $1 \mathrm{~h}$ at $68^{\circ} \mathrm{C}$ before an overnight incubation at $68^{\circ} \mathrm{C}$ in hybridization buffer containing $1 \mu \mathrm{g} / \mathrm{ml}$ digoxigenin-labeled probe. After slides were washed at $68^{\circ} \mathrm{C}$ for $1 \mathrm{~h}$ in buffer containing $50 \%$ formamide, $0.5 \mathrm{XSSC}$, and $1 \%$ SDS, they were washed for $1.5 \mathrm{~h}$ in buffer containing $50 \%$ formamide, 0.5 XSSC, and $0.1 \%$ Tween. To remove formamide, the slides were washed twice in 0.5XSSC. Finally, slides were washed twice in PBS/ $0.1 \%$ Tween at room temperature. Hybridized probe was detected using anti-digoxigenin alkaline phosphatase-conjugated antibody (1:2,000, Roche Biochemical, Indianapolis, IN) and visualized with NBT/BCIP (Sigma). After in situ hybridization, sections were post-fixed for $30 \mathrm{~min}$ in $4 \%$ paraformaldehyde in PBS, rinsed, and mounted in Fluoromount G (Southern Biotech, Birmingham, AL).

\section{ß-galactosidase staining}

Cochleae were isolated from Axin2 ${ }^{\mathrm{LacZ} /+}$ and wildtype mice. Following fixation in $4 \%$ paraformaldehyde in PBS for $1 \mathrm{~h}$, cochleae were washed with $2 \mathrm{mM} \mathrm{MgCl}_{2}$ in PBS twice for 5 min each at room temperature. Next, cochleae were incubated in x-gal $(1 \mathrm{mM})$ and x-gal mixer $(1: 40, v / v)$; x-gal mixer:

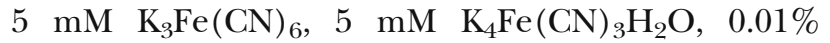
sodium deoxycholate, $0.2 \% \mathrm{NP}-40,2 \mathrm{mM} \mathrm{MgCl}_{2}$ (in PBS, $\mathrm{pH} 7.4$ ) for $1 \mathrm{~h}$ at $37^{\circ} \mathrm{C}$. Tissues were rinsed with PBS prior to cryosectioning and immunostained as described above. Control experiments found no nonspecific staining with this procedure in wild-type cochlea.

\section{Auditory brainstem responses}

Mice were anesthesized using ketamine $(100 \mathrm{mg} / \mathrm{kg})$ and xylazine $(10 \mathrm{mg} / \mathrm{kg})$. ABR signals were measured with an Opti-Amp 8002 amplifier (Intelligent Hearing Systems (IHS), Miami, FL) from a needle electrode positioned at the ventral surface of the tympanic bulla referenced to an electrode placed at the vertex of the skull. A ground electrode was attached to the hind leg. The 8-, 16-, and 32-kHz tone bursts were created with stimulus intensity ranging from 10 to $80 \mathrm{~dB}$ SPL in 5-dB increments and delivered with high-frequency transducers (IHS). Measuring parameters were consistent with previously described procedures and results (Zheng et al. 1999).

\section{Statistical analysis}

Statistical analyses were conducted using Microsoft Excel (Microsoft, Redmond, WA) and Origin softwares (OriginLab, Northampton, MA). One-tailed, unpaired 
Student's $t$ test and one-way ANOVA were utilized, with $p<0.05$ considered statistically significant.

\section{RESULTS}

Lgr5 expression in the embryonic cochlear duct

The Wnt target gene Lgr5 is upregulated in cells with active Wnt signaling in several organ systems, where Lgr5 ${ }^{\mathrm{EGFP} /+}$ transgenic mice have been utilized to report Lgr5 expression with EGFP (Barker et al. 2007; Jaks et al. 2008). In those systems, the reporter expression of Lgr5-EGFP has been validated to reflect $\operatorname{Lgr} 5$ expression and faithfully report active Wnt signaling. To characterize the expression pattern of active Wnt signaling in the developing cochlear duct, we analyzed the inner ears of the Lgr5 $5^{\mathrm{EGFP} /+}$ transgenic mice.

We first examined the embryonic cochlear duct at a developmental stage prior to the emergence of nascent hair cells. In the embryonic 15.5-day-old (E15.5) embryos, Lgr5-EGFP was expressed in a differential pattern along the apical-basal axis of the cochlear duct floor epithelium (in Fig. 2A). In the

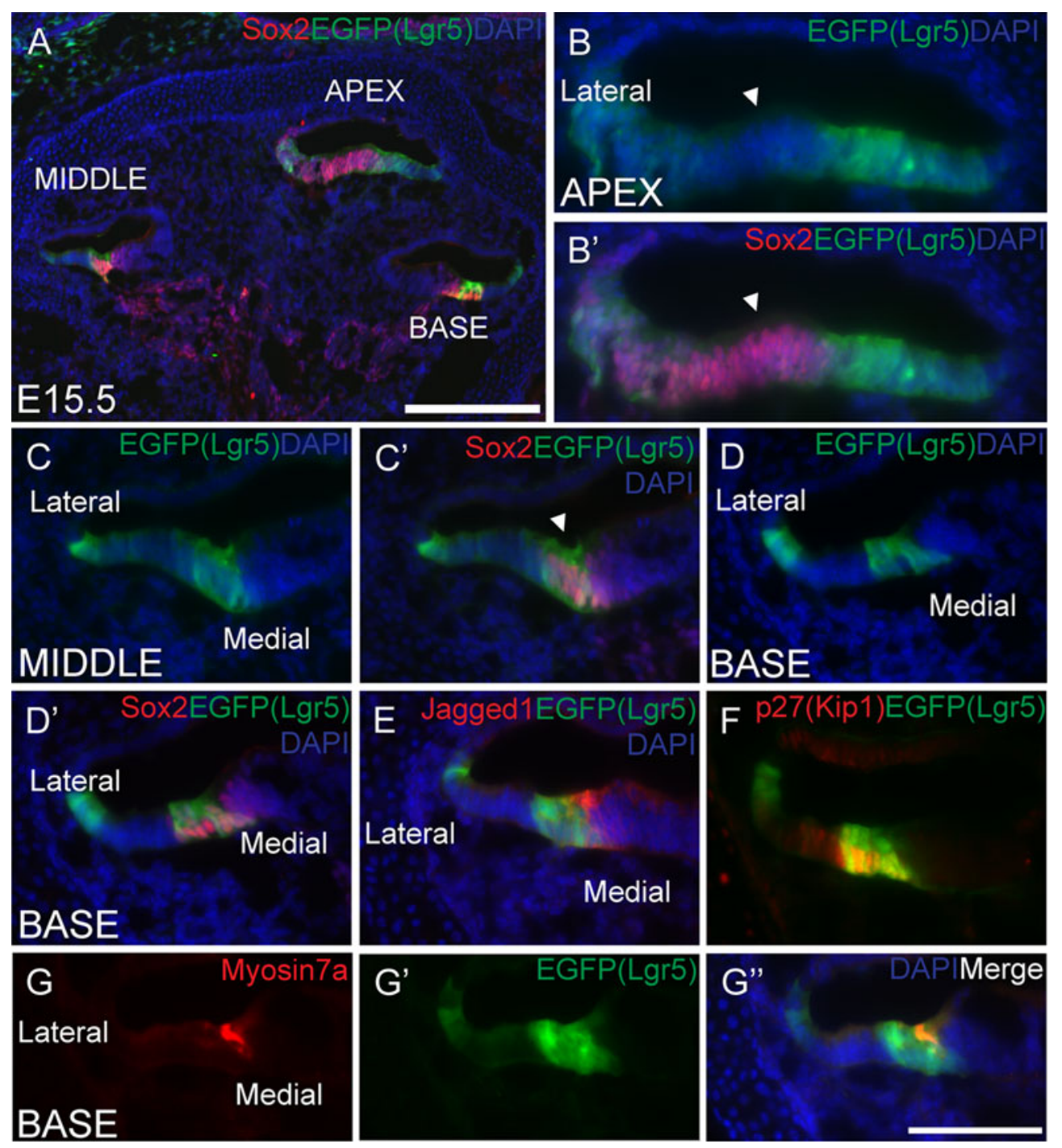

FIG. 2. Expression of Lgr5-EGFP along the E15.5 cochlear duct floor epithelium. A At low magnification, expression of Lgr5-EGFP was restricted to floor epithelium along the cochlear duct where a differential pattern was observed along the apical-basal axis. There was no detectable expression in the roof epithelium of the cochlear duct, cells surrounding the cochlear duct, or the nascent modiolus. $B, B^{\prime}$ In the apical turn, Lgr5EGFP was broadly expressed along the floor epithelium and noted to be most intense in the nascent strial region and medial to the Sox2-labeled prosensory region (arrowheads). C, $C^{\prime}$ The broad expression of Lgr5-EGFP was limited to the lateral half of the floor epithelium in the middle turn. The most intense expression was noted in the nascent strial region and in the central floor epithelium, partially overlapping with the Sox2-positive region (arrowhead). $D-G$ In the basal turn, Lgr5-EGFP was expressed in two bands of cells. The lateral band was located in the lateral sulcus, whereas the central band partially overlapped with the prosensory region as marked by Sox2 $\left(D^{\prime}\right)$, Jagged1 $(E)$, and p27(Kip1) (F). A single row of myosin7a-positive hair cells was detected within the central band of Lgr5-EGFP-positive cells $\left(G-G^{\prime \prime}\right)$. Scale bars, $250 \mu \mathrm{m}$ in $A$ and $50 \mu \mathrm{m}$ in $B-G$. 
apex, expression was broad, extending throughout the floor epithelium, with clearly distinct borders with the roof epithelium, which was thinner and completely devoid of reporter gene expression. The most robust expression was observed medial and lateral to the presumptive prosensory region, which was marked by Sox2 (arrowhead, Fig. $2 B-B^{\prime}$ ). Sox2 expression has been shown to mark the prosensory region which gives rise to the organ of Corti (Dabdoub et al. 2008; Kiernan et al. 2005). Lgr5-EGFP expression was present at a low level in this Sox2-positive prosensory region (Fig. $\left.2 B-B^{\prime}\right)$. In the middle and basal turns of the E15.5 cochlear duct, Lgr5-EGFP expression was more regionalized. In the middle turn, robust Lgr5EGFP expression was observed in the lateral strial and the Sox2-expressing prosensory regions, but Sox2 expression extended more medially into the presumptive greater epithelial ridge (GER; Fig. 2C-C'). Myosin7a is one of the earliest markers of hair cell differentiation (Sahly et al. 1997) and was not detected in the apical and middle turns at this developmental stage (not shown). In the basal turn, Lgr5-EGFP expression was completely segregated into two bands: one located on the lateral cochlear wall and the other in the central cochlear duct floor. The central band of the Lgr5-EGFP-positive region in the basal turn partially overlapped with the Sox2-positive domain (Fig. 2D- $D^{\prime}$ ).

To further characterize the Lgr5-EGFP-expressing cells in the central portion of the cochlear duct floor, we examined other markers of the prosensory region. Jagged1, a ligand of the Notch signaling pathway, is localized to the prosensory region by E15 (Morrison et al. 1999). Its expression also overlapped with the medial band of Lgr5-EGFP-positive cells ( $E$ in Fig. 2). The cyclin-dependent kinase inhibitor p27(Kip1) is another marker of the prosensory domain. By E16, the expression of $\mathrm{p} 27$ (Kip1) is restricted to the supporting cells of the sensory epithelium (Chen and Segil 1999). The central band of Lgr5-EGFPpositive cells partially overlapped with both the Jagged1and p27(Kip1)-expressing domains (Fig. 2E-F). Nascent myosin7a-positive hair cells first appeared in the medial strip of Lgr5-EGFP-positive cells in E15.5 basal cochlear duct (Fig. $2 G-G^{\prime \prime}$ ).

We next examined the E18.5 cochlear duct and again found a differential Lgr5-EGFP expression pattern along the apical-basal axis (Fig. 3A). Now, the apical turn resembled the E15.5 basal turn, suggesting a wave of maturation that develops from the base to the apex. A single row of myosin7a-positive hair cells (arrowhead) was present in the apical turn, where Sox2 was expressed in hair cells, adjacent supporting cells, and the GER medially (Fig. $3 B-B^{\prime \prime}$ ). Lgr5-EGFP expression was the most robust in the prosensory region medially and the lateral cochlear wall. The more mature middle turn contained four rows of myosin7a-positive hair cells (asterisks in Fig. $3 G-C^{\prime \prime}$,). This hair cell-bearing area at this or more mature developmental stages is henceforth referred to as the sensory region. At this developmental stage, both Sox2 and Lgr5-EGFP were expressed in hair cells and supporting cells. Outside the sensory region, Lgr5-EGFP expression was limited to the lateral GER, whereas Sox2 expression extended further medially (Fig. $3 G-C^{\prime \prime}$ ). In the more mature basal region, sensory hair cells, as marked by myo$\sin 7 \mathrm{a}$, have downregulated both Sox2 and Lgr5-EGFP (arrowheads in Fig. $3 D-D^{\prime \prime}$ ). In parallel, Lgr5-EGFP expression also decreased in a subset of supporting cells and became restricted to the third row of Deiters' cells, inner pillar cells, medial inner phalangeal cells, and the lateral GER (Fig. $3 D-D^{\prime \prime}$ ). The downregulation of Sox2 in hair cells was consistent with previous findings (Hume et al. 2007). These data indicate that Lgr5-EGFP is dynamically expressed in the embryonic cochlear duct and transiently expressed in the prosensory and sensory regions. To gain insight into the pattern of active Wnt signaling in the maturing sensory region, we next assessed Lgr5EGFP expression in the postnatal cochlea.

\section{Spatiotemporal expression of Lgr5 in the postnatal cochlea}

The postnatal 1-day-old (P1) cochlea, like the basal turn of the E18.5 cochlear duct, displayed Lgr5-EGFP expression in a subset of supporting cells in the sensory region (third row of Deiters' cells, inner pillar cells, and medial inner phalangeal cells); lateral GER; and the nascent stria vascularis on the lateral cochlear wall (Fig. $4 A, D$ ). Expression of Lgr5-EGFP on the lateral cochlear wall was noted to persist into adulthood (P30, data not shown). The Lgr5-EGFP reporter expression was identical to $\operatorname{Lgr} 5$ mRNA expression detected by in situ hybridization (Fig. $4 B$ ). In the P3 cochlea, we compared Lgr5-EGFP expression to three supporting cell markers: Prox1, p27(Kip1), and Jagged1. Prox1 is a homeobox transcription factor that is expressed in Deiters' cells and pillar cells in the postnatal cochlea (Bermingham-McDonogh et al. 2006). In the early postnatal cochlea, p27(Kip1) is expressed in Deiters' cells, pillar cells, inner phalangeal wells, Hensen's cells, Claudius' cells, and the lesser epithelial ridge (LER; Chen and Segil 1999), whereas Jagged1 is expressed in supporting cells in the sensory region and the GER (Oesterle et al. 2008). We noted Lgr5-EGFP expression in a subset of supporting cells in the sensory region and the GER (Fig. $4 C-C^{\prime \prime}, E$ ), a pattern remarkably different from Prox1, p27 (Kip1), or Jagged1. In both the P1 and P3 cochleae, an expression gradient was visible in the 


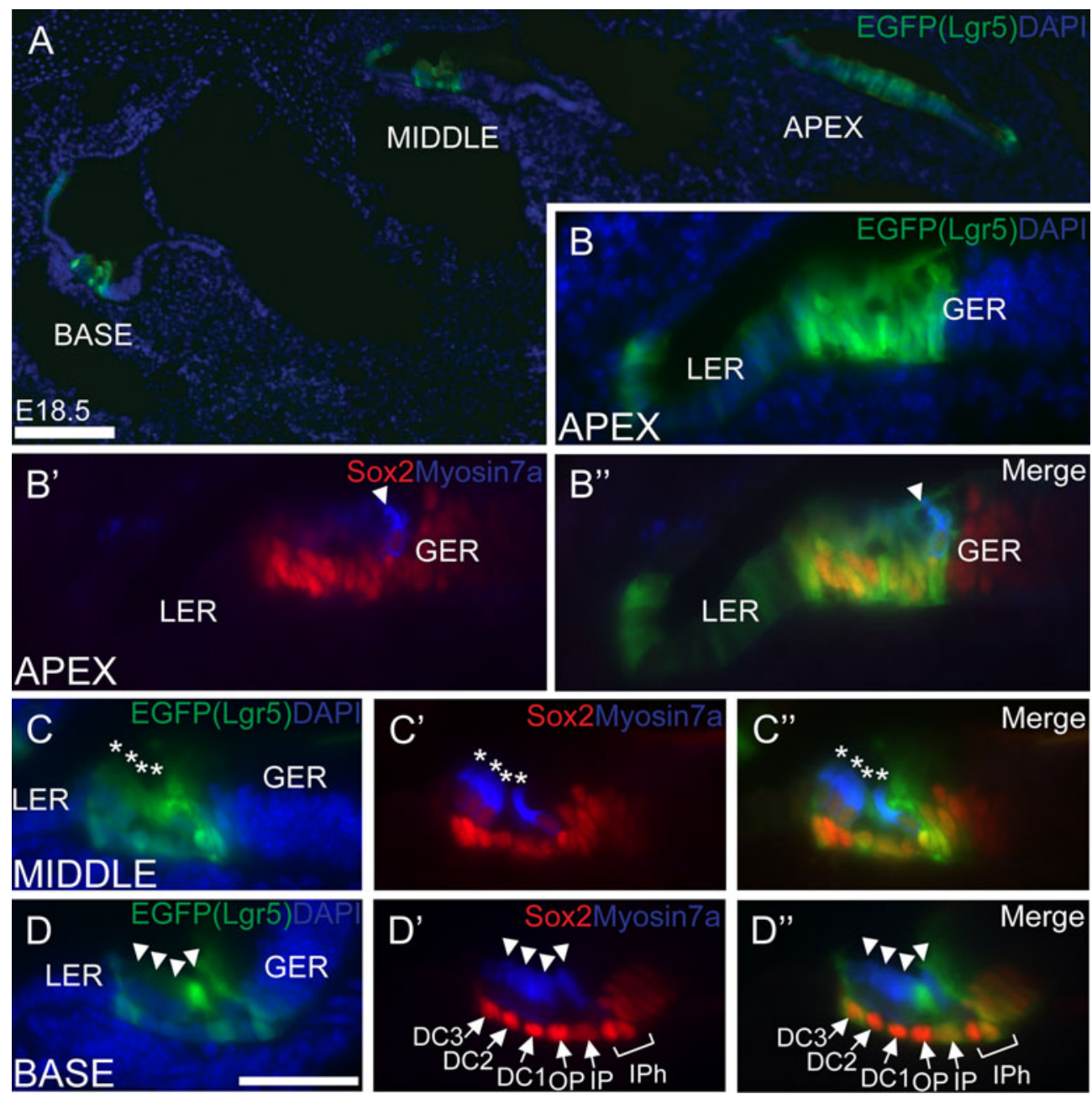

FIG. 3. Expression of Lgr5-EGFP among distinct cell types in the E18.5 cochlear duct. A Lgr5-EGFP was expressed in a differential pattern along the apical-basal axis of the E18.5 cochlear duct. Its expression was also limited to the floor epithelium and not detected in cells surrounding the cochlear duct or nascent modiolus. B-B" Lgr5-EGFP was broadly expressed along the floor epithelium in the apical turn, with the most robust expression noted in the lateral sulcus and the prosensory region medially. The medial Lgr5-EGFP-positive domain overlapped with the Sox2positive region and contained myosin7a-positive hair cells (arrowhead). $C-C^{\prime \prime}$ In the middle turn, Lgr5-EGFP expression was segregated into a band in the lateral sulcus (see $A$ ) and a central band, which partially overlapped with the Sox 2 marked region. Four rows of myosin7a-positive hair cells (asterisks), which co-expressed Sox2, were noted in the medial Lgr5-EGFP-positive region. Sox2 and Lgr5-EGFP were co-expressed in hair cells and supporting cells in the nascent organ of Corti. Lgr5-EGFP was expressed in the first two to three rows of cells in the lateral GER, whereas Sox2 expression spanned more medially in the GER. $D-D^{\prime \prime}$ In the basal turn, Lgr5-EGFP was expressed in the third row of Deiters' cells, inner pillar cells, the medial inner phalangeal cells, and the lateral GER. Its downregulation among hair cells (arrowheads) coincided with that of Sox2. DC Deiters' cells, OP outer pillar cells, IP inner pillar cells, IPh inner phalangeal cells, LER lesser epithelial ridge, GER greater epithelial ridge. Scale bars, $250 \mu \mathrm{m}$ in $A$ and $25 \mu \mathrm{m}$ in $B-D$.

lateral GER where Lgr5-EGFP expression was more intense laterally and gradually diminished along the strial-modiolar axis (Figs. $4 D-E, 5 A-A^{\prime \prime}$, and $6 A-A^{\prime \prime}$, $C)$. Beyond the first two to three rows of cells in the lateral GER, no Lgr5-EGFP was detected. Using a monoclonal antibody recognizing the extracellular domain of Lgr5 protein (Sasaki et al. 2010), we detected Lgr5 expression in a subset of supporting cells in the sensory region and the GER, corroborating the in situ hybridization data and the reporter gene expression (Fig. $6 B-B^{\prime \prime}$ ).
Between P3 and P12, the level of Lgr5-EGFP expression gradually decreased in the inner pillar cells, inner phalangeal cells, and the lateral GER (Figs. $4 E-I$ and $5 B-D$ ). During this early postnatal period, Lgr5-EGFP expression remained robust in the third row of Deiters' cells. Overall, the mRNA levels of $\operatorname{Lgr} 5$ significantly decreased $(74.3 \pm 5.1 \%, p<0.001)$ between $\mathrm{P} 2$ and $\mathrm{P} 15$ (Fig. $4 M$ ). In P12 or older cochleae, only the third row of Deiters' cells expressed Lgr5-EGFP (Figs. $4 I-L$ and $5 D-E)$. 

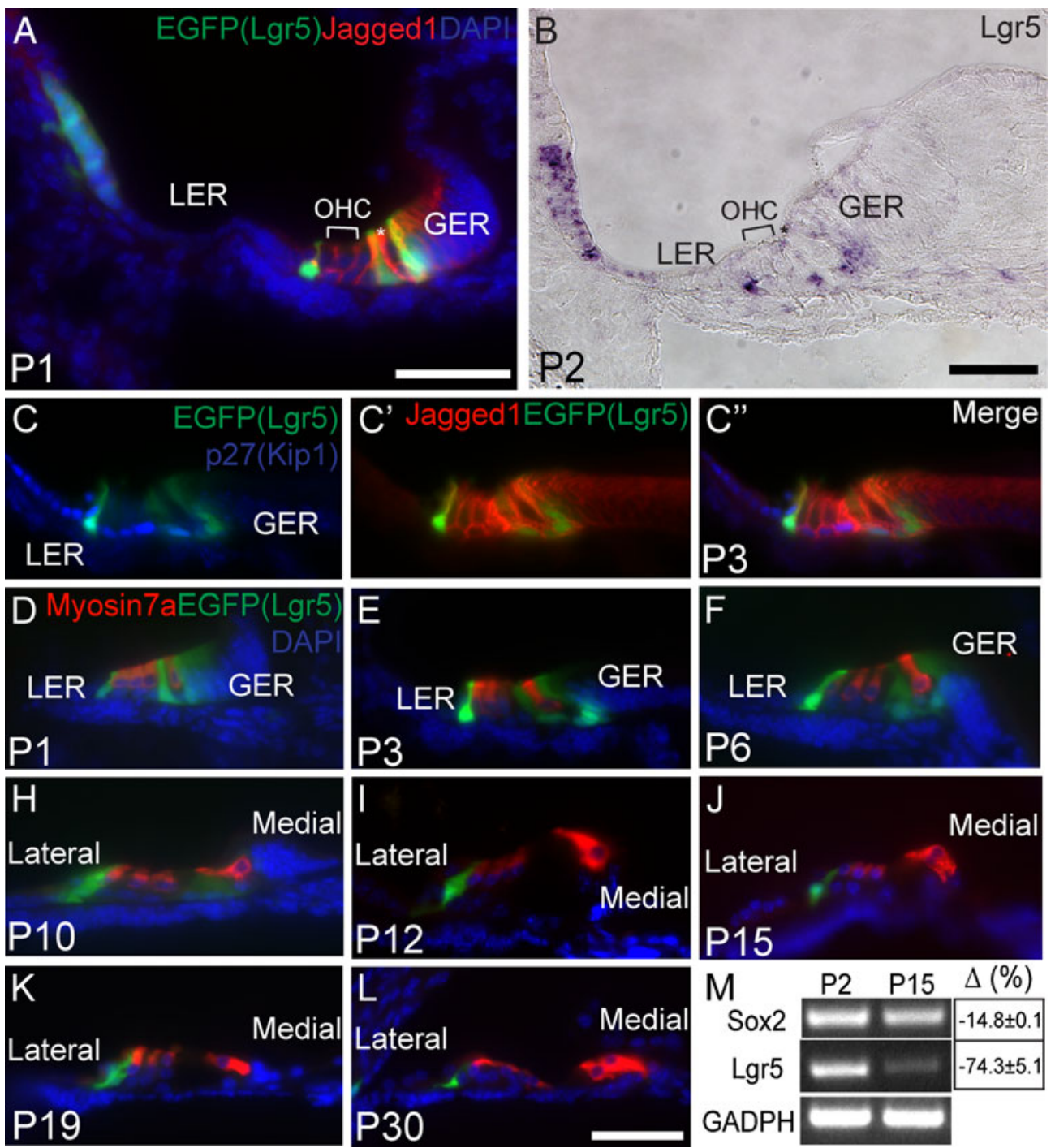

FIG. 4. Lgr5-EGFP expression in specific supporting cells in the neonatal and adult organ of Corti. $A, B$ Cryosections of Lgr 5 EGFP/+ cochlea ( $A$ ) and wild-type cochlea processed for in situ hybridization demonstrated Lgr5 expression on the lateral cochlear wall and distinct supporting cell types. $C-L$ Cryosections of cochleae were prepared from P1-P30 Lgr5 $5^{\text {EGF } /+}$ transgenic mice. Lgr5-EGFP was expressed in the third row of Deiters' cells, inner pillar cells, medial inner phalangeal cells, and the lateral GER during the first postnatal week. A decreasing gradient of Lgr5-EGFP expression was observed in the GER, with the lateral-most cells exhibiting the most robust expression. In the P3 cochlea, the cell cycle marker p27(Kip1) marked supporting cells including Hensen's cells (C), which did not express Lgr5-EGFP and are clearly distinct from the adjacent third row of Deiters' cells. Jagged1 was expressed on the surface membrane of supporting cells and the GER, with its expression sharply contrasted with that of Lgr5-EGFP in the P3 cochlea $\left(C^{\prime}\right)$. Between P3 and P12, the expression of Lgr5-EGFP gradually declined in the inner pillar cells, the medial row of inner phalangeal cells, and GER, but remained detectable in the third row of Deiters' cells. After P12, only the third row of Deiters' cells in the organ of Corti expressed Lgr5-EGFP. M RT-PCR and qPCR of cochleae from P2 to P15 wild-type mice demonstrated a significant decline in Lgr5 $(p<0.001)$ and Sox2 expression $(p<0.05)$. GAPDH expression did not change significantly. Results are shown as mean \pm SD. GER greater epithelial ridge, $L E R$ lesser epithelial ridge. Scale bars, $50 \mu \mathrm{m}$ in $A-L$.

Lgr5 deficiency leads to perinatal lethality caused by gastric distension; however, its inner ear phenotype was unknown (Barker et al. 2007; Morita et al. 2004). We examined the cochleae of homozygous P1 Lgr5 $5^{\mathrm{EGFP} / \mathrm{EGFP}}$ mice and found normal organization of hair cells and supporting cells within the organ of Corti (Fig. 6D-E) and normal morphology of the lateral cochlear wall (data not shown), suggesting that Lgr5 is not essential for cochlear development. Because the homozygous mice have two copies of the reporter gene, cells that express low levels of Lgr5-EGFP are detectable in the homozygous genotype. Cell types expressing low levels of Lgr5-EGFP include the first two rows of Deiters' cells, outer pillar cells, the lateral inner phalangeal cells, and all four rows of hair cells. These data indicate that $\operatorname{Lgr} 5$ expression is rapidly downregulated in specific supporting cells in the postnatal organ of Corti and becomes restricted to the third row of Deiters' cells in the mature organ. 


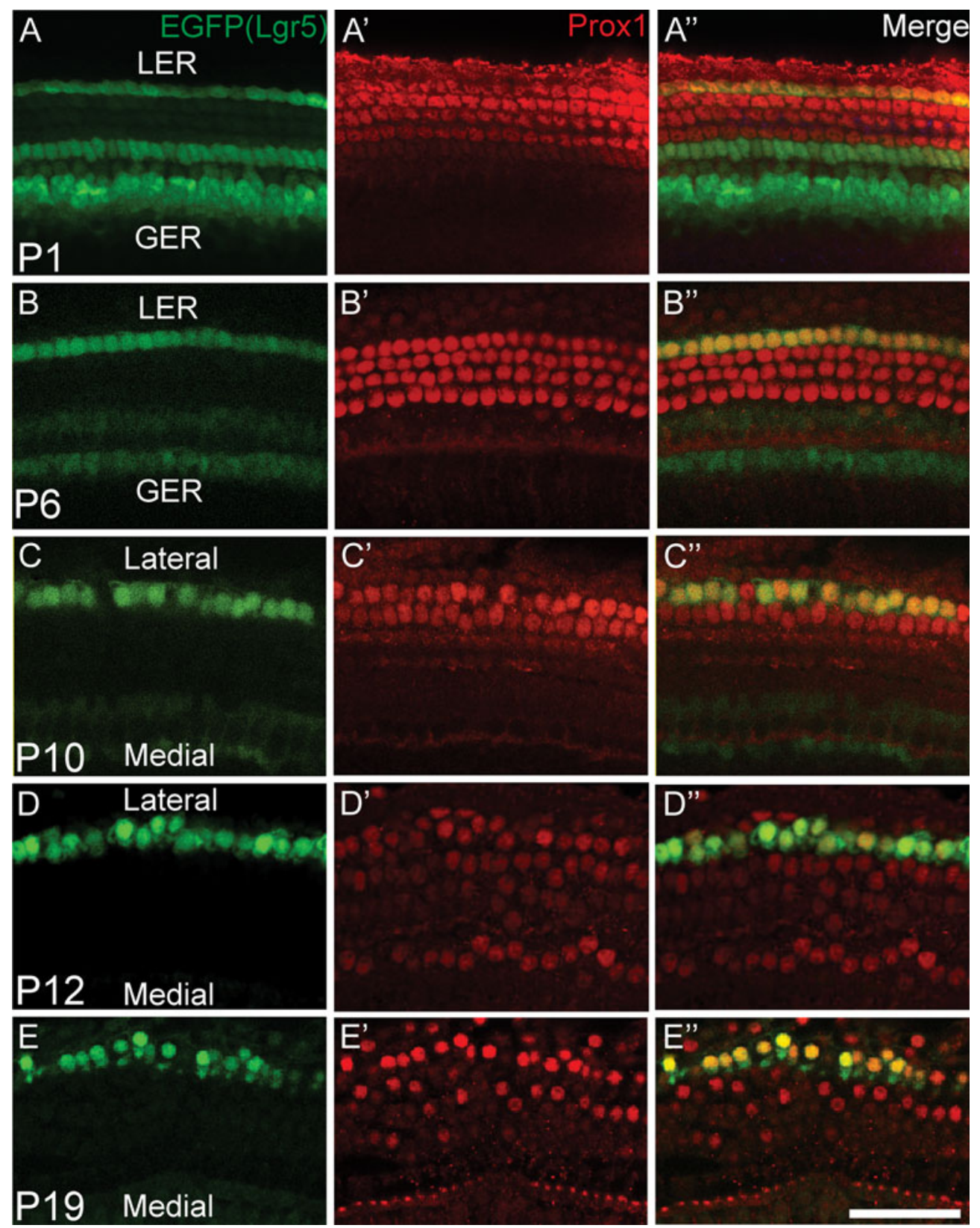

FIG. 5. Lgr5-EGFP expression becomes restricted to the third row of Deiters' cells with age. A-E Whole mounts of cochleae from P1-P30 $\mathrm{Lgr}^{\mathrm{EGFP} /+}$ transgenic mice were prepared and immunostained for Prox1, which marked Deiters' cells and pillar cells. Confocal images were obtained at the level of Deiters' cell nuclei. In the P1 cochlea, Lgr5-EGFP was expressed in the third row of Deiters' cells, inner pillar cells, medial inner phalangeal cells, and the lateral GER. Except in the third row of Deiters' cells, Lgr5-EGFP was downregulated in the sensory region between P1 and P12. After P12, Lgr5-EGFP was detectable only in the third row of Deiters' cells. Scale bars, $50 \mu \mathrm{m}$.

Wnt signaling regulates Lgr5 expression

In the gastrointestinal and integumentary systems, Wnt signaling controls Lgr5 expression (Jaks et al. 2008; Ootani et al. 2009). To determine whether Lgr5 expression is also modulated by Wnt signaling in the inner ear, we tested the effects of Wnt agonist and antagonist on cochlear explants. Purified Wnt3a activates canonical Wnt signaling by upregulating $\beta$ - catenin in target cells (Willert et al. 2003); Fz8CRD is a soluble analog of Frizzled receptors that bind and inhibit endogenous Wht proteins (DeAlmeida et al. 2007). When cochlear explants isolated from P1 wildtype mice were cultured with Wnt3a $(200 \mathrm{ng} / \mathrm{ml})$, $\operatorname{Lg} 5$ mRNA expression increased 2.0-fold $(p<0.01$, Fig. $7 D$ ), but Lgr5-EGFP expression remained restricted to specific supporting cell types and the lateral GER in Wnt3a-treated P1 Lgr5 ${ }^{\mathrm{EGFP} /+}$ cochleae 

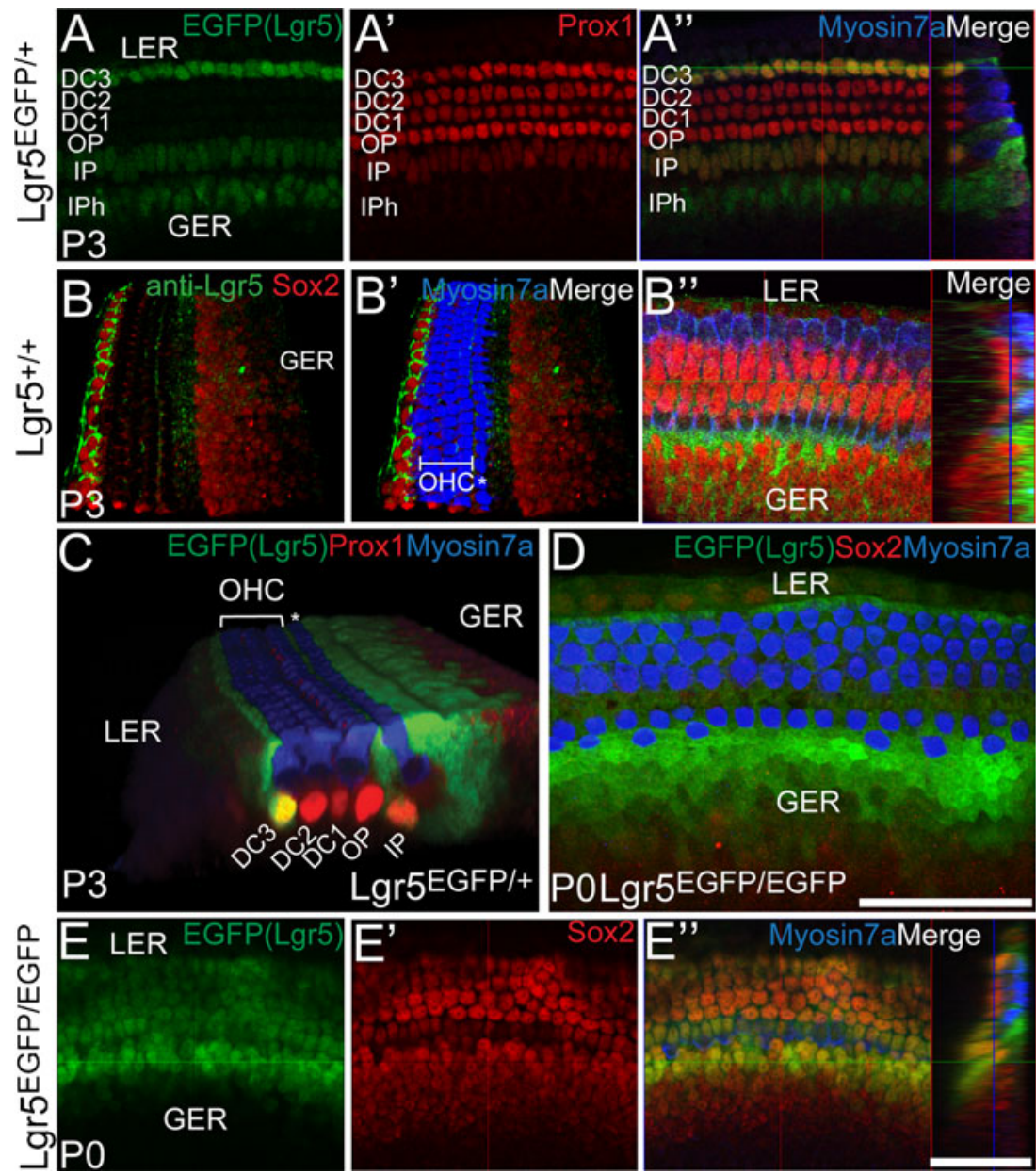

FIG. 6. Differential expression of Lgr5-EGFP in the Lgr5 $5^{\text {EGFP/ }}$ and Lgr5 $5^{\text {EGFP/EGFP }}$ cochleae. $A-A^{\prime \prime}$ Confocal images of whole mount of P3 Lgr $5^{\mathrm{EGFP} /+}$ cochleae were taken at the level of Deiters' cells nuclei. Lgr5-EGFP expression was noted in the third row of Deiters' cells, inner pillar cells, and medial inner phalangeal cells. Reconstruction of the Z-stack images shows the segmented pattern of Lgr5-EGFP expression among these supporting cell subtypes. Prox1 marked Deiters' and pillar cells. Myosin7a-positive hair cells did not express Lgr5-EGFP. B-B" Immunostaining for Lgr5, a transmembrane protein, in wild-type P3 cochlea demonstrated expression restricted to specific Sox2-positive supporting cell types and not myosin7a-positive hair cells. C Three-dimensional reconstruction of images illustrated that the expression of Lgr5EGFP was restricted to subtypes of supporting cells and lateral GER. D, E Whole mounts from P0 Lgr5 ${ }^{\text {EGFP/EGFP }}$ cochlea showed no hair cell and supporting cell disorganization. In contrast to the heterozygous P0 cochleae where Lgr5-EGFP was detected only in the third row of Deiters' cells, inner pillar cells, medial inner phalangeal cells, and the lateral GER, Lgr5-EGFP was also expressed in hair cells and other supporting cells in the homozygous cochleae. Confocal images captured at the level of hair cell bodies $(D)$ and Deiters' cell nuclei $(E)$ of the same cochlea are shown. $D C$ Deiters' cells, OP outer pillar cells, IP inner pillar cells, IPh inner phalangeal cells, OHC outer hair cells, LER lesser epithelial ridge, GER greater epithelial ridge. Asterisk denotes inner hair cells in $B$ and $C$. Scale bars, $50 \mu \mathrm{m}$.

(Fig. $7 A^{\prime}$ ). Treatment with Wnt3a also significantly increased the expression of two other Wnt target genes, Axin 2 and $S p 5$, but did not alter that of the hair cell-specific gene, Brn3.1, and supporting cell gene, $p 27($ Kip1). In the absence of exogenous Wnt3a, Lgr5-EGFP expression rapidly declined in cultured P6 Lgr5 ${ }^{\mathrm{EGFP} /+}$ cochleae (Fig. $7 B$ ), whereas supplementation with exogenous Wnt proteins prevented this decline (Fig. $7 B^{\prime}$ ), suggesting that Lgr5EGFP expression is dependent on active Wnt signaling. This Wnt responsiveness was limited to specific cell types as the pattern of Lgr5-EGFP expression was similar between the Wnt3a-treated cochleae from P1 and P6 mice. We further probed the possibility that Lgr5-EGFP is dependent on Wnt signaling by inhibiting endogenous Wnt proteins with the soluble Frizzled receptor analog, Fz8CRD. P3 Lgr5 ${ }^{\mathrm{EGFP} /+}$ cochleae treated with Fz8CRD $(25 \mu \mathrm{g} / \mathrm{ml})$ no longer expressed detectable Lgr5EGFP, whereas cochleae incubated in control media (IgG) continued to have robust Lgr5-EGFP expression (Fig. $7 C-C^{\prime}$ ). Quantitative analysis found a $63.7 \pm 6.0 \% \quad(p<0.001)$ reduction of $\mathrm{Lgr} 5$ transcripts in the Fz8CRD-treated wild-type cochlea, but Brn3.1 and $p 27($ Kip1) expression was unchanged. Parallel experiments found a significant decrease in both 

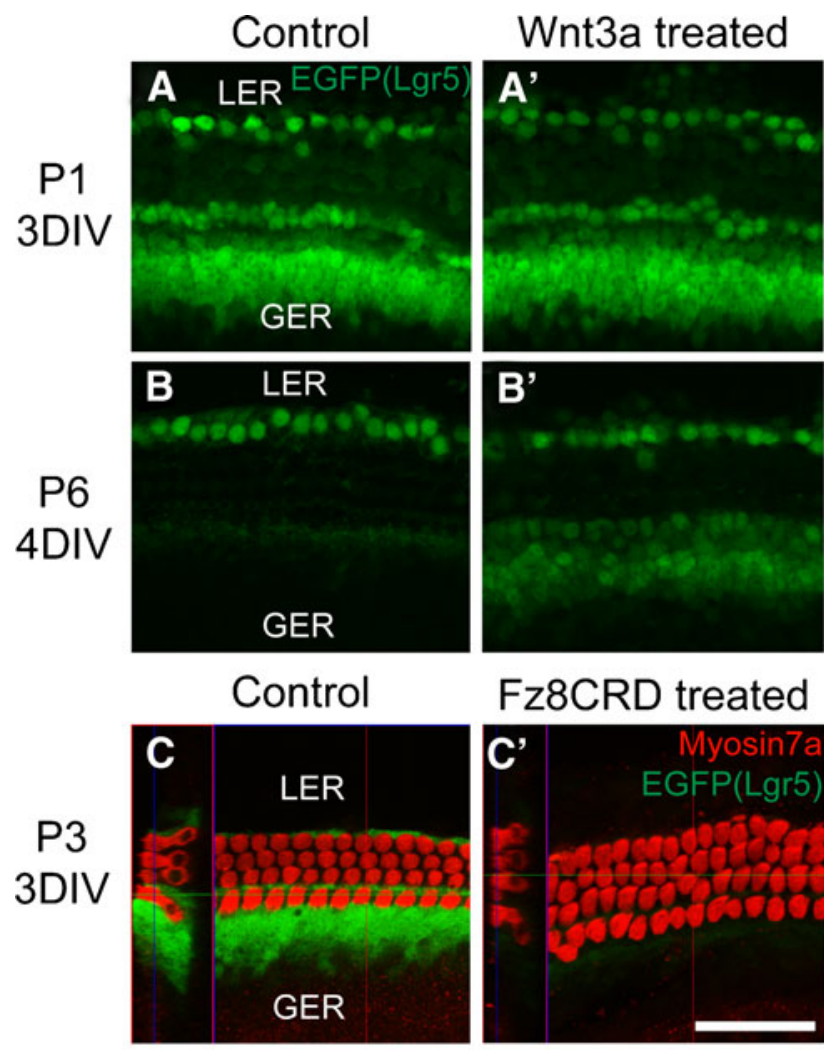

D

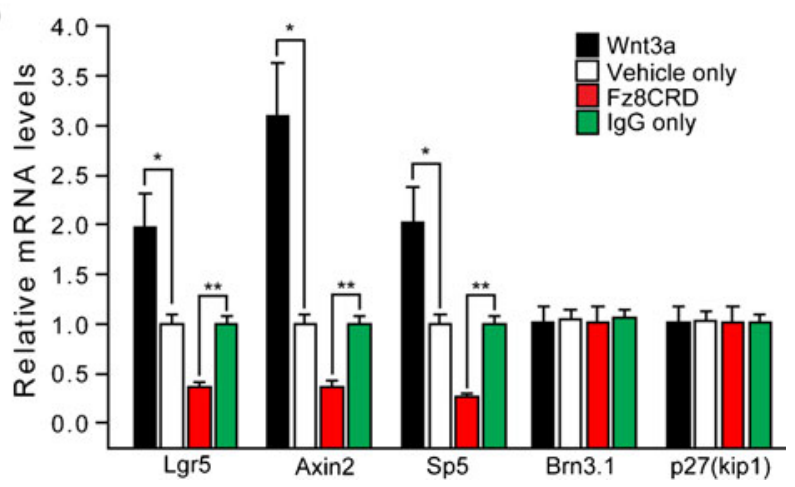

FIG. 7. Wnt signaling regulates Lgr5 expression. A, B Cochlear explants from $\mathrm{P} 1$ and $\mathrm{P} 6$ Lgr5 $5^{\mathrm{EGFP} /+}$ mice were incubated with purified Wnt3a (200 ng/ml) or vehicle only (1\% CHAPS) for 34 days. Treatment with $\mathrm{Wnt} 3 \mathrm{a}$ in the P1 cochleae did not alter the pattern of Lgr5-EGFP expression, while treatment of the P6 cochleae prevented the decline of its expression. $C$ Treatment of cochlear explants from P3 Lgr5 ${ }^{\text {EGFP/+ }}$ with Fz8CRD $(25 \mu \mathrm{g} / \mathrm{ml})$, an inhibitor of endogenous Wnt proteins, effectively quenched Lgr5-EGFP expression. $D$ Quantitative PCR of P3 wild-type cochlear explants treated with Wnt3a, Fz8CRD, and their respective drug vehicles for 3 days. Wnt3a significantly increased the expression of Lgr5, as well as the Wnt target genes Axin2 and Sp5 (*p<0.01 for all three), while treatment with Fz8CRD significantly decreased their expression levels (** $p<0.001$ for all three). Expression of Brn3.1 and p27(kip1) was not affected by manipulation of Wnt signals. Experiments were triplicated and expression levels were calculated using the $\Delta \Delta C_{\mathrm{T}}$ method with $\beta$-actin as the endogenous reference (Livak and Schmittgen 2001). Scale bar, $50 \mu \mathrm{m}$.
Axin2 and $S p 5$ expression as a result of Wnt inhibition $(p<0.001$ for both, Fig. $7 D)$. These results lead us to conclude that Lgr5 expression is regulated by Wnt signals and that only specific cochlear cell types are competent to upregulate Lgr5 in response to Wnt signals.

\section{Lgr5 ${ }^{\text {EGFP/+ }}$ phenotype and Lgr5-EGFP-positive cells}

Heterozygous $\operatorname{Lgr} 5^{\mathrm{EGFP} /+}$ mice are reported to have no abnormal phenotypes, but no auditory function has been described (Barker et al. 2007). We compared the ABRs of P30 $\mathrm{Lgr5}^{\mathrm{EGFP} /+}$ mice to their agematched, wild-type littermates and found no significant difference between the two genotypes (one-way ANOVA, $p=0.78$; Fig. $8 A$ ).

To further examine whether Lgr5-EGFP reporter activity reflects $\operatorname{Lgr} 5$ gene expression, we isolated the Lgr5-EGFP-positive cell population from P3 $\mathrm{Lgr}^{\mathrm{EGFP} /+}$ mice using flow cytometry (Fig. $8 B$ ). The EGFPpositive cell population constituted about $2.1 \%$ of the P3 cochlea. Analysis by quantitative PCR found that the EGFP-positive cells expressed significantly more copies of $\operatorname{Lgr} 5 \mathrm{mRNA}$ than Lgr5-EGFP-negative cells (73.6 \pm 8.3 -fold difference, $p<0.001$; Fig. $8 C$ ). This analysis, along with the in situ hybridization (Fig. $4 B$ ) and immunochemistry data (Fig. 6B), supports the conclusion that Lgr5-EGFP reporter activity, like in other organs (Barker et al. 2007; Jaks et al. 2008), accurately reports $\operatorname{Lgr} 5$ expression in the cochlea. Because our data also suggest that $\operatorname{Lgr} 5$ expression is modulated by Wnt signals, we next compared its expression pattern to another Wnt target gene, Axin2.

Axin2 expression in the developing cochlear duct

Axin2 is a feedback inhibitor that is upregulated during active Wnt signaling in many tissue types (Jho et al. 2002; Kalani et al. 2008; Lustig et al. 2002; Zeng and Nusse 2010). In the cochlea, we found that expression of Axin2, like $\operatorname{Lgr} 5$, is modulated by Wnt signals (Fig. $7 D$ ). Since expression of Wnt target genes can be context-dependent and vary among different tissue types (Barolo and Posakony 2002), we compared the spatiotemporal expression pattern of Axin2 to Lgr5 in the inner ear. In the E14.5 basal cochlear duct, in situ hybridization experiments detected Axin 2 expression in cells surrounding the cochlear duct (Fig. 9A). Faint expression was noted in the medial quadrant of the cochlear duct epithelium. By E15.5, Axin 2 expression in the extraductal tissues consolidated in the medial and lateral poles, while the dorsal and ventral regions demonstrated a low level of 

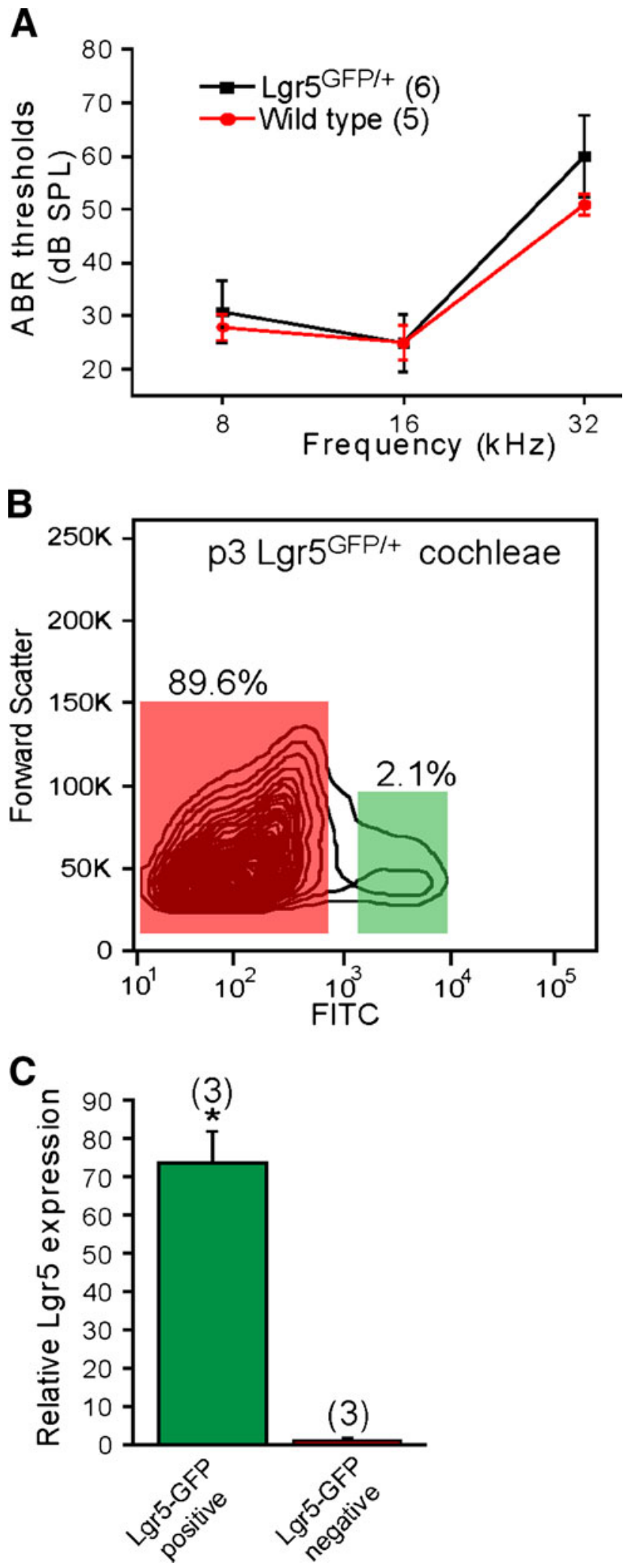

expression (Fig. 9B). In the medial cochlear duct floor epithelium, faint Axin2 expression was again noted. As the scala media expanded and the scala tympani formed at E18.5, Axin2 transcripts were detected in the tympanic border cells on the under-
FIG. 8. Lgr5 $^{\mathrm{EGFP} / \pm}$ mice have normal auditory function. A P30 heterozygotes and wild-type littermates were evaluated; all homozygotes died during the early postnatal periods. There were no significant differences in the auditory brainstem responses $(p=0.78)$ between the two groups. $B, C$ P3 cochleae from $\mathrm{Lgr}^{\mathrm{EGFP} /+}$ mice were dissociated into single cells to allow for the purification of Lgr5EGFP-positive cells via flow cytometry. Lgr5-EGFP-positive cells constituted $\sim 2.1 \%$ cochlear cells. Quantitative PCR demonstrated that these cells are significantly more enriched for Lgr5 expression than other cochlear cells $(p<0.001)$. Error bars indicate SD.

surface of the basilar membrane facing the scala tympani (Fig. 9C). Cells in the spiral limbus, lining the Reissner's membrane, and underlying the nascent stria vascularis robustly expressed Axin2. Within the cochlear duct floor, Axin2 mRNA was detectable in the GER (asterisk in Fig. 9D). In the P2 cochlea, Axin2 expression remained robust in the tympanic border cells beneath the organ of Corti (asterisk in Fig. 9E), but decreased in the spiral limbus and the lateral cochlear wall. Axin 2 mRNA was not detectable in the prosensory and sensory domains at all ages tested. The Axin $2^{\mathrm{LacZ} /+}$ mice revealed an identical expression pattern of Axin2 expression in the P3 cochlea (Fig. 9F). Taken together, these data led us to conclude that while Axin2 and Lgr5 are both Wnt target genes, they are differentially expressed in and around the developing cochlear duct.

\section{DISCUSSION}

The canonical Wnt pathway plays a critical role in organogenesis in several organ systems (Ikeya et al. 1997; Li et al. 2002; Majumdar et al. 2003; Yamaguchi et al. 1999). Studies examining the role of this signaling pathway during the development of the cochlear duct are just emerging. To augment our tools to identify Wnt-activated cells in the inner ear, we have hereby validated and characterized the expression of two Wnt target genes, Lgr5 and Axin2.

Previously, Wnt signaling was shown to mediate otic versus epidermal fate decisions during the formation of otic placode (Lillevali et al. 2006; Ohyama et al. 2006). In the developing chicken inner ear, Sienknecht and Fekete $(2008,2009)$ characterized dynamic expression patterns of multiple Wnt proteins, their respective family of Frizzled receptors, and inhibitory proteins in both prosensory and non-sensory cells between E4 and E15. Notably, several Wnt proteins are transiently expressed in the prosensory region. Forced activation of the Wnt pathway via the transfection of $\beta$-catenin, the central mediator of active canonical Wnt signaling, or via the addition of exogenous Wnt3a to the developing cochlear duct prior to prosensory specification led to inner ear malformation and induced ectopic sensory patches (Stevens et al. 2003). These results point to a 


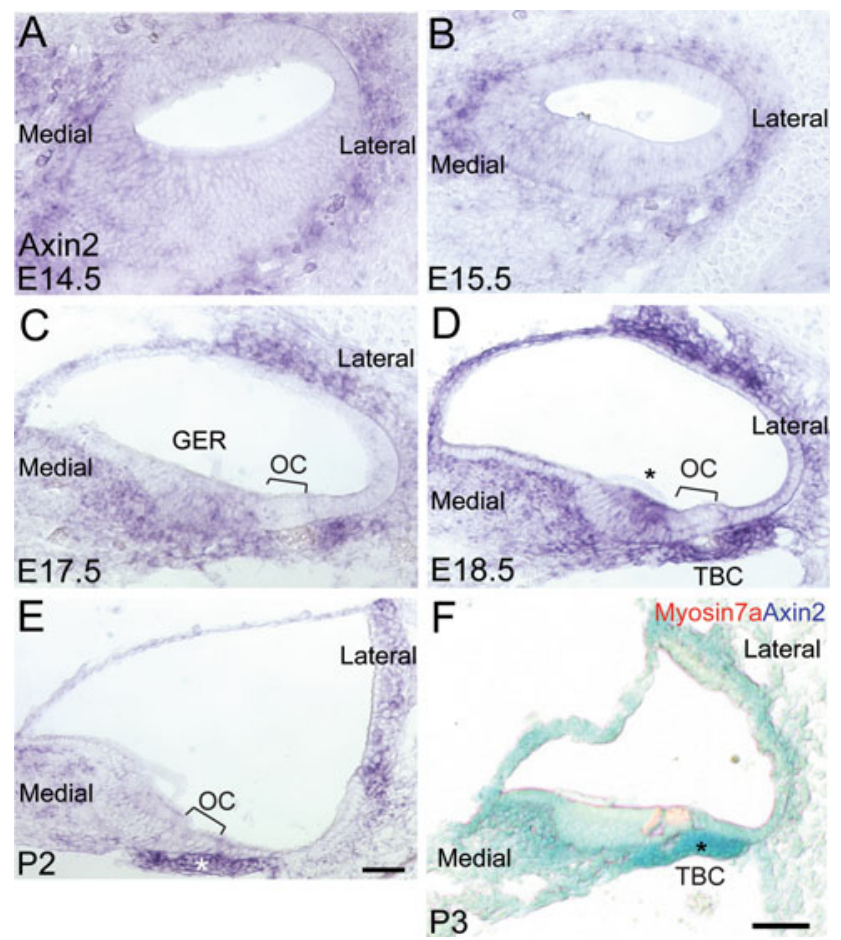

FIG. 9. Axin2 expression in the embryonic and postnatal cochleae. $A, B$ In situ hybridization detected Axin2 expression in cells surrounding the E14.5 and E15.5 cochlear duct. No significant expression was observed within the cochlear duct epithelium at these ages. C, D At E17.5 and E18.5, Axin2 was expressed in three main regions: (1) tympanic border cells (asterisks), which occupy the undersurface of the basilar membrane facing scala tympani; (2) stromal cells in the upper lateral cochlear wall; and (3) stromal cells medial to the GER which later forms the spiral limbus. Within the floor epithelium of the cochlear duct, Axin2 expression was noted in the medial GER (asterisk). E In the P2 cochlea, Axin2 expression remained robust in the tympanic border cells (asterisk) and appeared less intense in the spiral limbus and the lateral cochlear wall. $F, G$ Cryosections of cochleae from P3 Axin $2^{\text {LacZ/+ }}$ transgenic mice were stained for B-galactosidase activity. Robust expression was noted in the tympanic border cells (asterisk). Basal turns were examined in AF. TBC tympanic border cells, OC organ of Corti, GER greater epithelial ridge. Scale bars, $50 \mu \mathrm{m}$.

role of the Wnt pathway in prosensory domain formation and morphogenesis. Microarray analyses have demonstrated that several Wnt genes are expressed in the embryonic and neonatal mammalian cochlea (Chen and Corey 2002; Sajan et al. 2007). In the postnatal rat cochlea, Daudet et al. (2002) have identified transcripts of individual Wnt proteins and Frizzled receptors. Interpretation of the expression patterns of Wnt proteins and Frizzled receptors is difficult because of the myriad of possible combinations; therefore, many groups have used Wnt target genes to identify Wnt-activated cells (Barolo 2006).

Lgr5 is an orphan G protein-coupled receptor with a large leucine-rich domain, but lacks a clearly defined function (Hsu et al. 1998). Investigators have shown that $\operatorname{Lgr} 5$ expression is regulated by Wnt signaling and acts as a marker for endogenous stem cells in rapidly proliferating organs (Barker et al. 2007, 2010; Jaks et al. 2008; Ootani et al. 2009). Our data indicate that $L g r 5$ expression was dependent on endogenous Wnt proteins and promoted by exogenous Wnt3a, an established canonical Wnt protein (Willert et al. 2003). Based on these results, we conclude that $\operatorname{Lgr} 5$ is also a Wnt target in the inner ear. Other Wnt proteins can act as morphogens that control the planar cell polarity of hair cells during development via the non-canonical Wnt pathway (B-catenin-independent; Dabdoub et al. 2003; Dabdoub and Kelley 2005; Qian et al. 2007); it is therefore possible for other Wnt proteins to regulate Lgr 5 expression via this mechanism. Unlike the rapidly proliferating organs where $\operatorname{Lgr} 5$ has been previously characterized to mark somatic stem cells, the prosensory and sensory regions expressing $\operatorname{Lgr} 5$ are postmitotic (Chen and Segil 1999; Ruben 1967). Future cell tracing experiments will likely help elucidate the significance of Lgr5-positive cell lineage.

The observation that Lgr5 is dynamically expressed in the cochlear duct epithelium, including the prosensory region, raises the possibility that Wnt signaling may play a role in cell fate determination in the developing cochlear duct. Interestingly, Lgr5EGFP expression rapidly disappears in hair cells and a subset of supporting cells. The notion that Wnt signaling plays a role in cell fate determination in the inner ear is supported by two previous studies: overexpression of $\beta$-catenin, the central player of the canonical Wnt pathway, upregulates Atoh1 (Shi et al. 2010) and induces ectopic sensory patches (Stevens et al. 2003). While our data indicate that $\operatorname{Lgr} 5$ is not required for cochlear development, its expression likely reflects the pattern of Wnt-activated cells within the cochlear ductal epithelium.

The differential expression between $\operatorname{Lgr} 5$ and Axin2 at several developmental stages suggests that Wnt targets are cell type-dependent and indicates that other Wnt-activated cells exist outside the cochlear ductal epithelium. Such tissue-specific and development-specific behavior for Wnt target genes has also been reported in other organ systems (Barolo 2006; Barolo and Posakony 2002), and hence the rationale of examining multiple Wnt target genes using gainand loss-of-function assays in the current study. Similar contextual expression patterns have been observed with the BATGAL reporter mouse, a TCF reporter (Barolo 2006; Maretto et al. 2003), and possibly explain the discrepancy between our data and those of Qian et al. (2007) who found no BATGAL expression in or surrounding the embryonic cochlear duct. TOPGAL is yet another transgenic TCF reporter mouse line that has been shown to label cells with active Wnt signaling in multiple tissue types (DasGupta and Fuchs 1999; Maretto et al. 2003). However, false-negative results have been reported 
with this mouse line since it occasionally failed to label tissues with known active Wnt signaling (Dessimoz et al. 2005; Geng et al. 2003; Riese et al. 1997). While we conclude that Lgr5-positive and Axin2-positiive cells represent Wnt-activated cells, the sum of both reporter activities still might not reveal the full degree of Wnt activity in the developing and maturing cochlea, which is a limitation of our study. While functional studies will be necessary to further delineate the role of Wnt signaling in the development and maturation of the cochlea, our study provides a framework for those studies as we show which cell types in the cochlear duct are actively receiving Wnt signals.

In conclusion, our study has identified a dynamic expression pattern for the Wnt target gene Lgr5 in both the embryonic and postnatal cochlear duct. Its expression pattern contrasted with that of another Wnt target gene, Axin2. While these two markers indicate the presence of active Wnt signaling in different cell types in the developing and mature inner ear, further analyses will be necessary to elucidate the functional role of Wnt signaling in the development and maintenance of the organ of Corti.

\section{ACKNOWLEDGMENTS}

The authors thank Xin Hong Lim, Zahra Sayyid, and Catherine Ray for excellent technical assistance and Stefan Heller, Kazuo Oshima, Fuxin Shi, and Mirna Mustapha for advice and comments. This study was supported by NIDCD P30DC010363, a Stanford University Dean's Fellowship (to R.C.), Stanford University Medical Scholars Program, Howard Hughes Medical Institute Training Fellowship (both to T.A.J.), NIDCD R01DC009991 (to O.B-McD), the American Otological Society, the Triological Society, a Percy Memorial Award, and NIDCD K08DC011043 (all to A.G.C.).

\section{Conflict of Interest}

The authors have no conflict of interest to declare.

\section{REFERENCES}

Barker N, van Es JH, Kuipers J, Kujala P, van den Born M, Cozijnsen M, Haegebarth A, Korving J, Begthel H, Peters PJ et al (2007) Identification of stem cells in small intestine and colon by marker gene Lgr5. Nature 449:1003-1007

Barker N, Huch M, Kujala P, van de Wetering M, Snippert HJ, van Es JH, Sato T, Stange De, Begthel H, van den Born M et al (2010) Lgr5(+ve) stem cells drive self-renewal in the stomach and build long-lived gastric units in vitro. Cell Stem Cell 6:25-36

BAROLO S (2006) Transgenic Wnt/TCF pathway reporters: all you need is Lef? Oncogene 25:7505-7511
Barolo S, Posakony JW (2002) Three habits of highly effective signaling pathways: principles of transcriptional control by developmental cell signaling. Genes Dev 16:1167-1181

Bermingham-McDonogh O, Oesterle EC, Stone JS, Hume CR, Huynh HM, Hayashi T (2006) Expression of Proxl during mouse cochlear development. J Comp Neurol 496:172-186

Chen ZY, CoRey DP (2002) An inner ear gene expression database. J Assoc Res Otolaryngol 3:140-148

Chen P, Segil N (1999) p27(Kip1) links cell proliferation to morphogenesis in the developing organ of Corti. Development 126:1581-1590

Chen P, Johnson JE, Zoghbi HY, Segil N (2002) The role of Math1 in inner ear development: uncoupling the establishment of the sensory primordium from hair cell fate determination. Development 129:2495-2505

Dabdoub A, Kelley MW (2005) Planar cell polarity and a potential role for a Wnt morphogen gradient in stereociliary bundle orientation in the mammalian inner ear. J Neurobiol 64:446-457

Dabdoub A, Donohue MJ, Brennan A, Wolf V, Montcouguiol M, Sassoon DA, Hsein JC, Rubin JS, Salinas PC, Kelley MW (2003) Wnt signaling mediates reorientation of outer hair cell stereociliary bundles in the mammalian cochlea. Development 130:2375-2384

Dabdoub A, Puligilla C, Jones JM, Fritzsch B, Cheah KS, Pevny LH, Kelley MW (2008) Sox2 signaling in prosensory domain specification and subsequent hair cell differentiation in the developing cochlea. Proc Natl Acad Sci USA 105:18396-18401

DAsGuPTA R, Fuchs E (1999) Multiple roles for activated LEF/TCF transcription complexes during hair follicle development and differentiation. Development 126:4557-4568

Daudet N, Ripoll C, Moles JP, Rebillard G (2002) Expression of members of Wnt and Frizzled gene families in the postnatal rat cochlea. Brain Res Mol Brain Res 105:98-107

DeAlmeida Vi, Miao L, Ernst JA, Koeppen H, Polakis P, Rubinfeld B (2007) The soluble wnt receptor Frizzled8CRD-hFc inhibits the growth of teratocarcinomas in vivo. Cancer Res 67:5371-5379

Dessimoz J, Bonnard C, Huelsken J, Grapin-Botton A (2005) Pancreas-specific deletion of beta-catenin reveals Wnt-dependent and Wnt-independent functions during development. Curr Biol 15:1677-1683

Geng X, Xiao L, Lin GF, Hu R, Wang JH, Rupp RA, Ding X (2003) Lef/Tcf-dependent Wnt/beta-catenin signaling during Xenopus axis specification. FEBS Lett 547:1-6

Hartman BH, Basak O, Nelson BR, Taylor V, Bermingham-McDonogh O, ReH TA (2009) Hes5 expression in the postnatal and adult mouse inner ear and the drug-damaged cochlea. J Assoc Res Otolaryngol 10:321-340

Hayashi T, Cunningham D, Bermingham-McDonogh O (2007) Loss of Fgfr3 leads to excess hair cell development in the mouse organ of Corti. Dev Dyn 236:525-533

Hayashi T, Ray CA, Bermingham-McDonogh O (2008) Fgf20 is required for sensory epithelial specification in the developing cochlea. J Neurosci 28:5991-5999

Holiyday M, McMahon JA, McMahon AP (1995) Wht expression patterns in chick embryo nervous system. Mech Dev 52:9-25

Hsu SY, LIang SG, Hsueh AJ (1998) Characterization of two LGR genes homologous to gonadotropin and thyrotropin receptors with extracellular leucine-rich repeats and a G protein-coupled, seven-transmembrane region. Mol Endocrinol 12:1830-1845

Hume CR, Bratt DL, Oesterle EC (2007) Expression of LHX3 and SOX2 during mouse inner ear development. Gene Expr Patterns 7:798-807

Ikeya M, Lee SM, Johnson JE, McMahon AP, Takada S (1997) Wht signalling required for expansion of neural crest and CNS progenitors. Nature 389:966-970 
Jaks V, Barker N, Kasper M, van Es JH, Snippert HJ, Clevers H, TOFTGARD R (2008) Lgr5 marks cycling, yet long-lived, hair follicle stem cells. Nat Genet 40:1291-1299

Jasoni C, Hendrickson A, Roelink H (1999) Analysis of chicken Wnt13 expression demonstrates coincidence with cell division in the developing eye and is consistent with a role in induction. Dev Dyn 215:215-224

Jho EH, Zhang T, Domon C, Joo CK, Freund JN, Costantini F (2002) Wnt/beta-catenin/Tcf signaling induces the transcription of Axin2, a negative regulator of the signaling pathway. Mol Cell Biol 22:1172-1183

Kalani MY, Cheshier SH, Cord BJ, Bababeygy SR, Vogel H, Weissman IL, Palmer TD, Nusse R (2008) Wnt-mediated self-renewal of neural stem/progenitor cells. Proc Natl Acad Sci USA 105:16970-16975

Kiernan Ae, Pelling Al, leung KK, Tang AS, Bell DM, Tease C, Lovell-Badge R, Steel KP, Cheah KS (2005) Sox2 is required for sensory organ development in the mammalian inner ear. Nature 434:1031-1035

LeE YS, Liu F, SEgIL N (2006) A morphogenetic wave of p27Kip1 transcription directs cell cycle exit during organ of Corti development. Development 133:2817-2826

Li C, XiaO J, Hormi K, Borok Z, Minoo P (2002) Wnt5a participates in distal lung morphogenesis. Dev Biol 248:68-81

Lillevali K, Haugas M, Matilainen T, Pussinen C, Karis A, SALminen M (2006) Gata3 is required for early morphogenesis and Fgf10 expression during otic development. Mech Dev $123: 415-429$

Livak KJ, Schmittgen TD (2001) Analysis of relative gene expression data using real-time quantitative PCR and the 2(-Delta Delta C (T) ) method. Methods 25:402-408

Logan CY, Nusse R (2004) The Wnt signaling pathway in development and disease. Annu Rev Cell Dev Biol 20:781-810

Lustig B, Jerchow B, Sachs M, Weiler S, Pietsch T, Karsten U, van de Wetering M, Clevers H, Schlag PM, Birchmeier W et al (2002) Negative feedback loop of Wnt signaling through upregulation of conductin/axin2 in colorectal and liver tumors. Mol Cell Biol 22:1184-1193

Majumdar A, Vainio S, Kispert A, McMahon J, McMahon AP (2003) Wnt11 and Ret/Gdnf pathways cooperate in regulating ureteric branching during metanephric kidney development. Development 130:3175-3185

Maretto S, Cordenonsi M, Dupont S, Braghetta P, Broccoli V, Hassan AB, Volpin D, Bressan GM, Piccolo S (2003) Mapping Wnt/beta-catenin signaling during mouse development and in colorectal tumors. Proc Natl Acad Sci USA 100:3299-3304

Morita H, Mazerbourg S, Bouley DM, Luo CW, Kawamura K, Kumabara Y, Baribault H, Tian H, Hsueh AJ (2004) Neonatal lethality of LGR5 null mice is associated with ankyloglossia and gastrointestinal distension. Mol Cell Biol 24:9736-9743

Morrison A, Hodgetts C, Gossler A, Hrabe de Angelis M, Lewis J (1999) Expression of Deltal and Serrate1 (Jagged1) in the mouse inner ear. Mech Dev 84:169-172

Morsli H, Choo D, Ryan A, Johnson R, Wu DK (1998) Development of the mouse inner ear and origin of its sensory organs. J Neurosci 18:3327-3335

Oesterle EC, Campbell S, Taylor RR, Forge A, Hume CR (2008) Sox2 and JAGGED1 expression in normal and drug-damaged adult mouse inner ear. J Assoc Res Otolaryngol 9:65-89

Ohyama T, Mohamed OA, Taketo MM, Dufort D, Groves AK (2006) Wnt signals mediate a fate decision between otic placode and epidermis. Development 133:865-875
Ootani A, Li X, Sangiorgi E, Ho QT, Ueno H, Toda S, Sugihara H, Fujimoto K, Weissman IL, Capecchi MR et al (2009) Sustained in vitro intestinal epithelial culture within a Wnt-dependent stem cell niche. Nat Med 15:701-706

Qian D, Jones C, Rzadzinska A, Mark S, Zhang X, Steel KP, Dai X, Chen $P$ (2007) Wnt5a functions in planar cell polarity regulation in mice. Dev Biol 306:121-133

Radde-Gallwitz K, Pan L, Gan L, Lin X, Segil N, Chen P (2004) Expression of Islet1 marks the sensory and neuronal lineages in the mammalian inner ear. J Comp Neurol 477:412-421

Reya T, Clevers H (2005) Wnt signalling in stem cells and cancer. Nature 434:843-850

Riccomagno MM, TAKAdA S, Epstein DJ (2005) Wnt-dependent regulation of inner ear morphogenesis is balanced by the opposing and supporting roles of Shh. Genes Dev 19:1612-1623

Riese J, Yu X, Munnerlyn A, Eresh S, Hsu SC, Grosschedl R, Bienz M (1997) LEF-1, a nuclear factor coordinating signaling inputs from wingless and decapentaplegic. Cell 88:777-787

RubeL EW (1978) Ontogeny of structure and function in the vertebrate auditory system. In: Jacobson M (ed) Handbook of sensory physiology, IX. Springer, New York, pp 135-237

Ruben RJ (1967) Development of the inner ear of the mouse: a radioautographic study of terminal mitoses. Acta Otolaryngol Suppl 220:221-244

Sahly I, El-Amraoui A, Abitbol M, Petit C, Dufier JL (1997) Expression of myosin VIIA during mouse embryogenesis. Anat Embryol (Berl) 196:159-170

SAJAN SA, Warchol ME, LovetT M (2007) Toward a systems biology of mouse inner ear organogenesis: gene expression pathways, patterns and network analysis. Genetics 177:631-653

Sasaki Y, Kosaka H, Usami K, Toki H, Kawai H, Shiraishi N, Ota T, Nakamura K, Furuya A, Satoh M et al (2010) Establishment of a novel monoclonal antibody against LGR5. Biochem Biophys Res Commun 394:498-502

Shi F, Cheng YF, WANg XL, Edge AS (2010) Beta-catenin up-regulates Atoh1 expression in neural progenitor cells by interaction with an Atoh1 3' enhancer. J Biol Chem 285:392-400

Sienknecht UJ, Fekete DM (2008) Comprehensive Wnt-related gene expression during cochlear duct development in chicken. J Comp Neurol 510:378-395

Sienknecht UJ, FekETE DM (2009) Mapping of Wnt, frizzled, and Wnt inhibitor gene expression domains in the avian otic primordium. J Comp Neurol 517:751-764

Soshnikova N, Zechner D, Huelsken J, Mishina Y, Behringer RR, Taketo MM, Crenshaw EB 3rd, Birchmeier W (2003) Genetic interaction between Wnt/beta-catenin and BMP receptor signaling during formation of the AER and the dorsal-ventral axis in the limb. Genes Dev 17:1963-1968

Stevens CB, Davies AL, Battista S, Lewis JH, Fekete DM (2003) Forced activation of Wnt signaling alters morphogenesis and sensory organ identity in the chicken inner ear. Dev Biol 261:149-164

Willert K, Brown JD, Danenberg E, Duncan AW, Weissman IL, Reya T, YATES JR 3RD, Nusse R (2003) Wnt proteins are lipid-modified and can act as stem cell growth factors. Nature 423:448-452

Yamaguchi TP, Bradley A, McMahon AP, Jones S (1999) A Wnt5a pathway underlies outgrowth of multiple structures in the vertebrate embryo. Development 126:1211-1223

ZeNG YA, Nusse R (2010) Wnt proteins are self-renewal factors for mammary stem cells and promote their long-term expansion in culture. Cell Stem Cell 6:568-577

ZHENG QY, JOHNSON KR, ERWAY LC (1999) Assessment of hearing in 80 inbred strains of mice by ABR threshold analyses. Hear Res 130:94-107 